\title{
Double-Strand-Break Repair Protein Rad21 Homolog
}

National Cancer Institute

\section{Source}

National Cancer Institute. Double-Strand-Break Repair Protein Rad21 Homolog. NCI

Thesaurus. Code C93087.

Double-strand-break repair protein rad21 homolog (631 aa, $\sim 72 \mathrm{kDa}$ ) is encoded by the human RAD21 gene. This protein is involved in DNA repair, cell cycle-dependent chromosomal cohesion and apoptosis. 